\title{
Enabling Social Justice through Progressive Taxation in 'Discriminated' Societies
}

\author{
Ray Titus \\ Alliance School of Business, Alliance University, Bangalore - 562106, Karnataka, India. \\ E-mail address: ray.titus@alliance.edu.in
}

\begin{abstract}
"The social system is not an unchangeable order beyond human control but a pattern of human action."

John Rawls (1971, p. 102)
\end{abstract}

\begin{abstract}
The advocates of taxes point to its legitimacy as derived from the need for government to work for the people. Those who oppose taxes call it a burden imposed on the people, benefitting none than those in government and bureaucracy. The latter who advocate free markets believe the 'invisible hand' to be the better arbitrator to social justice. To put the debate on taxes in perspective, it is important to consider the need for social justice against a backdrop of societies that have practiced discrimination based on caste. Such societies stratify people by birth based on the castes they are born into. Caste based discrimination on its part has systematically ensured subjection of certain classes, with minimal access to fundamental rights. This in turn has ensured such classes live their lives in near penury. This research paper looks at class based discrimination as a preceding social more in the demand for progressive taxation.
\end{abstract}

Keywords: Caste; Discrimination; Progressive Taxation; Social More

\section{INTRODUCTION}

The seemingly straightforward relationship between taxing a population in a 'progressive' way and letting that achieve social justice isn't really that straightforward. Even James Mead's treatise, "we should strive . . to arrange for direct international transfers of income from those to whom income means little to those to whom income means much", is neither palatable, especially for the moneyed class, nor easy to achieve. In societies where wealth creation has been an individualistic pursuit, the desire to part with a portion of one's wealth in the name of taxes doesn't come easy. This despite the lure of contributing to larger social good. The pertinent question in such a circumstance is, 'why should one be responsible for another's upkeep?'. If a social circumstances begin at an even keel for all who seek their own personal good, why should one man's fortune compensate towards alleviating another's misery?

Culture is why societies differ. Cultural norms are why some societies pursue individualism as a right, whilst others gravitate towards collectivism. In the former, government intervention aimed at social good is often seen as a transgression by the state into 
individual liberty. The best example to this would be the opposition to universal healthcare in the United States of America. There are quite some people who believe healthcare isn't a universal right. And even if it is, paying for it through raising taxes so the ones who don't have healthcare benefit isn't acceptable. The stark contrast to such social attitudes can be seen in collectivistic societies. Collectivists see government as the legitimate provider of social good. At times such societies take social welfare to an extreme of 'entitlement' Citizens foster the belief that they are entitled to products and services, and that it is the duty of government to be the provider.

The willingness to contribute to a tax kitty that accounts for income re-distribution is always under question. More so, when redistributed wealth is culled out of 'earned' as against 'inherited' wealth. Earned wealth brings with it a greater sense of ownership, therefore a lesser desire to part with it. Inherited on the other hand is more conducive to being taken away in the form of taxes. Now if one were to assume a lack of desire to contribute to taxes when the wealth's self-made, what could the justification be to the act of taxing earned wealth? In fact, 'tax cuts' touted by governments as letting people keep their wealth is seen as a fallacious act. As Thomas Sowell (2010) states and asks, 'When you refrain from raising someone's taxes, you are not "giving" them anything. Even if you were actually cutting their tax rate - which is out of the question today - you would still not be "giving" them anything, but only allowing them to keep more of what they have earned. Is the government doing any of us a big favor by not taking even more of what we have worked for? Is it not an insult to our intelligence to say that the government is "giving" us something by not taxing it away?'

Thus the pointed issue that invites much debate is the justification in taxation. When are taxes in a progressive manner or otherwise justified? When is it moral to have government tax people according to their wealth and redistribute what's collected as tax kitty? The answer and the justification that supports taxation lies in the study of a social mores and what that's done to the prevalence of social justice. The question that be asked is, how evenly keeled is a society, or was to its inhabitants? Did every citizen have access to the same level playing field when it came to wealth creation? If the answer is a no, it then requires an intervention be brought in to set a level playing field. The intervention specifically should seek to set right social injustices that have long been perpetrated in a society. And in doing so the objective must be to raise the disadvantaged to a position from where they can, using social benefits, partake of social progress.

\section{PROGRESSIVE TAXATION AND THE ENABLEMENT OF JUSTICE}

The argument to letting progressive taxation do its work of justice holds water only if there's ample evidence to show, in the first place, the existence of social injustice. That is, a precedence of social injustice is what brings to fore the need for social justice. More so, when there is an economic implication to it. Else progressive taxation would only breed sloth, for the spoils of one's labor will count only to feed the slothful who by choice will not engage in that very labor, or to that same degree. Which is why it is argued that taxes that progressively take from income earners is relevant to geographies where there have been in place social systems that bred social injustice. Such systemic social hierarchies entrenched for ages ensure the majority remained in abject poverty for no reason other than having been by birth marked for a status that brought with it almost no opportunity for social progress. 


\section{SOCIAL INEQUALITIES AND SOCIAL MORES}

In considering inequties one must make a distinction between what is natural and what is the work of man. What is natural can neither be tagged as just nor unjust. Merely finding oneself by birth to be bound to a certain circumstance does not automatically deem it unfair. It is but then a statement of fact. What is just or unjust refers to the way social institutionalization deals with such facts. Aristocratic and caste societies are unjust because they make these contingencies the ascriptive basis for belonging to more or less enclosed and privileged social classes (John Rawls 1971). In hierarchical societies, downward leveling of norms may block members of historically oppressed groups from participating in mainstream society (Portes, 1998; Baum, 1999; Kawachi, 2000).

Note that societies have their own unique ways in building social frameworks that guide behavior. Some keep it open, others closed. Some keep it flat where others prefer hierarchies. Each society has its justification for why things are framed the way they are. Again, each society sees its own institutionalization as justified. But keeping in mind that some principles are non-negotiable universally, the question to be asked is one about freedom. How free are people, or were in a society to pursue their own unique definition of happiness within the strictures of the law? Were the laid down laws non-discriminatory? Did they promote fairness without compunction? Or did they seek to keep sections of a society under bondage. In answering these questions one would find that many societies didn't in fact promote and sustain equality under law. In fact it was the very same law that was used to sustain and embed discrimination. Thus what many societies bred were deep injustices for centuries. One such society was based on what is termed the Caste System.

\section{CASTE SYSTEM}

India in many ways can be tagged a Caste society. The New Shorter Oxford English Dictionary defines Caste as "a Hindu hereditary class of socially equal persons, united in religion and usually following similar occupations, distinguished from other castes in the hierarchy by its relative degree of purity or pollution." A Caste system can be defined as a type of social structure that divides people on the basis of inherited social status. It was during the British colonial rule in India that a common theory of caste, as we have come to understand it today, was first articulated (Cohn, 1996; Dirks, 2001).

Caste affiliations in India primarily flow to either a birth group (Jati) or a class (Varna) (Narasimhachary, 2002). From this very 'natural' flow arise acts of injustice in Caste societies that pervade almost all spheres of human life. Take for example one's choice of profession. The Caste system has ensured that generation after generation of a particular caste engages in only one profession. Even when it could be the socially degrading profession of 'Manual scavenging' that Indian law has banned (Economist, 2008). Such a 'by birth' lot is mainly reserved for the 'Dalits'** in India. 'Dalit' is a term which has had increasing currency in recent years in India. Literally, it means 'the oppressed'. It encompasses peoples who used to be called 'untouchables', or 'Harijans'; who are often also referred to as 'Scheduled Castes', because of the way they are referred to in the constitution of India (Dalit Solidarity Network, 2006). Though caste system gets primarily identified as being part of Indian society, the phenomenon of social exclusion isn't restricted to India alone. Early social anthropological studies, particularly those carried out during 1950s and 1960s, often pointed to the existence of 
caste based hierarchies and untouchability in other countries of South Asia as well (see, for example Hofer, 2005; Banks, 1971; Leach, 1971; Barth, 1971).

It was but natural that the embedding of caste system within societies came from a legitimacy that was derived from the practice of religion. But the practice wasn't restricted only to ideology. Instead it transgressed into other areas including the socio-economic system, cultural discourse and even political arenas. The stranglehold the caste system achieved further ensured the disenfranchised classes remained barred from participating in anything that could promise social progress.

Now the larger question that needs to be asked is whether the caste system systematically ensured certain classes in society were confined to generational penury. To that, the answer is an unequivocal yes. For centuries the caste system oppressed certain sections of societies while giving others the sanction to both oppress and also enjoy the labor of the oppressed. And such practices continue, still. Despite the fact that governmental initiatives have tried to lift the Dalits out of poverty through a 'job reservation' program, its effects have been negligible (Table 1-5).

This is partly due to a mindset problem that affects both the oppressed and the oppressor. The Oppressed believe it is their lot to do what's dictated by a social system that has existed for centuries. The oppressor believes the Dalit is not worthy of any tasks other than those assigned to by the Caste system. As Bezwada Wilson, son of a manual scavenger and founder of Dalits Human Rights Group states, 'the greatest difficulty was to convince his own community that carrying other people's excreta-manually picked up and carried on the head in baskets -was not their destiny; that it was not their past sins that had condemned them to a life of such humiliation. Their lot was due to the apathy of other humans and a selfish caste system (Sarabhai, 2010).

Thus it can be seen that the caste system is a major barrier to reducing income inequality due to the difficulty of moving out of one's expected role and therefore income bracket (Munshi and Rosenweig, 2005).

Furthermore one of the most striking features of the caste system in countries where it is practiced is the association of Dalit communities with certain types of jobs. For example, the cleaning of streets and latrines, dealing with dead animals, casual and bonded labour on land are identified with Dalit communities. Not only are these low status jobs, invariably they are also low paid jobs. Another common feature of Dalit life is residential segregation. Dalits of South Asia live in segregated settlements away from the main village, or in the urban slums where living conditions are generally poor (Jodhka and Shah, 2010).

Table 1. Government Employment under Reservation.

\begin{tabular}{|c|c|c|c|}
\hline Year & Dalits & Adivasis** & Others \\
\hline 1956 & 212,754 & 22,549 & $1,184,748$ \\
\hline 2003 & 540,220 & 211,345 & $2,517,780$ \\
\hline
\end{tabular}

Source: National commission for SC and ST and annual Report of Department of Personnel. 
Table 2. Percentage Share on Government Employment.

\begin{tabular}{|c|c|c|c|}
\hline Year & Dalits & Adivasis & Others \\
\hline 1956 & 14.98 & 1.59 & 83.43 \\
\hline 2003 & 16.52 & 6.46 & 77.01 \\
\hline
\end{tabular}

Source: Thorat 2005, 'Persistent Poverty - Why SC \& ST stay chronically poor' DFID Working paper.

Table 3. Employment under reservation in Public Sector Undertakings.

\begin{tabular}{|c|c|c|c|}
\hline Year & Dalits & Adivasis & Others \\
\hline 1970 & 40,640 & 12,309 & 494,680 \\
\hline 2003 & 296,388 & 138,504 & $1,198,106$ \\
\hline
\end{tabular}

Source: Thorat 2005, 'Persistent Poverty - Why SC \& ST stay chronically poor' DFID Working paper.

Table 4. Percentage share in Public Sector Undertakings.

\begin{tabular}{|c|c|c|c|}
\hline Year & Dalits & Adivasis & Others \\
\hline 1970 & 7.42 & 2.25 & 90.33 \\
\hline 2003 & 18.15 & 8.48 & 73.37 \\
\hline
\end{tabular}

Source: Thorat 2005, 'Persistent Poverty - Why SC \& ST stay chronically poor' DFID Working paper.

Table 5. Percentage Share of Employees in Public Sector Banks.

\begin{tabular}{|c|c|c|c|c|c|c|}
\hline Posts & $\mathbf{1 9 7 8}$ & $\mathbf{1 9 7 8}$ & $\mathbf{1 9 7 8}$ & $\mathbf{2 0 0 0}$ & $\mathbf{2 0 0 0}$ & $\mathbf{2 0 0 0}$ \\
\hline & SC & ST & Others & SC & ST & Others \\
\hline Officers & 2.04 & 0.34 & 97.62 & 12.51 & 4.22 & 83.27 \\
\hline Clerks & 10.32 & 1.82 & 87.86 & 14.88 & 4.76 & 80.36 \\
\hline Sub Staff & 16.25 & 2.09 & 81.67 & 24.47 & 6.25 & 69.28 \\
\hline
\end{tabular}

Source: National Commission for SC and ST.

** Adivasis are India's tribal people and are significant group outside the caste system, referred to as the Scheduled Tribes.

\section{ECONOMIC AND OTHER IMPLICATIONS OF A CASTE SYSTEM}

Inequalities perpetrated by the Caste system aren't economic alone, though its immediate fallout is the former. Take wages in the Sindh province in Pakistan. A survey conducted among the Hindu SCs of Sindh revealed that nearly 85 per cent of them earn less than 3000 Pakistani 
rupees (around 36 US \$) per month, far below the official minimum wage of 4,600 rupees. Scheduled Caste workers also pointed to widespread discrimination against them. A majority of them (58 per cent) reported that they get lesser wages than upper castes Muslim and Hindu workers for the same type of work.

Caste based inequalities also extend to the other resource frontiers too. If one were to look at monetary indicators (Table 6-8) such as levels of poverty and Standard of Living, it would point to a vast disparity between those who fall into the Scheduled Caste and Tribe and those who don't.

Dalits also face discrimination in accessing public services. For example, as many as 77 per cent reported having been denied services of barber and 90 per cent reported that the local restaurant served them tea and food in separate utensils. Many Dalits felt that they were harshly treated to the extent of being hated by the dominant groups. In India in the state of Tamil Nadu, when a Dalit comes to an upper Caste community area, he is required to remove his footwear while passing through the area. In schools too, Dalit children who are made to sit in the last rows and often treated badly by the teachers. They are even asked to stay back after schools to sweep the school courtyard and clean latrines. In fact a survey showed that nearly 63 per cent of the respondents reported having experienced caste related discrimination in their personal/ everyday life. A number of those who reported having faced caste related discrimination in businesses was lesser though not insignificant (42.4 per cent).

Table 6. SC \& ST Monetary Indicators.

\begin{tabular}{|c|c|c|c|c|}
\hline Poverty & SC & ST & Non SC/ST & All \\
\hline $\begin{array}{c}\text { Proportion of Urban population in } \\
\text { poverty (\%), (2000) }\end{array}$ & 38 & 35 & 221 & 24 \\
\hline $\begin{array}{c}\text { Proportion of Rural population in } \\
\text { poverty (\%), (2000) }\end{array}$ & 36 & 46 & 21 & 27 \\
\hline Standard of Living & 609 & 691 & $933^{*}$ & 855 \\
\hline $\begin{array}{c}\text { Urban Monthly per capita } \\
\text { Expenditure (Rupees), (1999-2000) }\end{array}$ & 419 & 388 & $513 *$ & 486 \\
\hline $\begin{array}{c}\text { Urban Monthly per capita } \\
\text { Expenditure (Rupees), (1999-2000) }\end{array}$ & 57,908 & 68,763 & 159,745 & 144,330 \\
\hline $\begin{array}{c}\text { Value of Average Urban Household } \\
\text { Assets (Rupees), (1991) }\end{array}$ & 49,189 & 52,660 & 134,500 & 107,007 \\
\hline $\begin{array}{c}\text { Value of Average Rural Household } \\
\text { Assets (Rupees), (1991) }\end{array}$ & 2,513 & 1,570 & 3,859 & 3,618 \\
\hline $\begin{array}{c}\text { Average Urban Household Debt } \\
\text { (Rupees), (1991) }\end{array}$ & 1,394 & 838 & 2,249 & 1,908 \\
\hline $\begin{array}{c}\text { Average Urban Household Debt } \\
\text { (Rupees), (1991) }\end{array}$ & & & \\
\hline
\end{tabular}

* Extrapolated from Population proportions

+ Derived from NSS Data

MINISTRY OF PLANNING \& PROGRAMME IMPLEMENTATION HOUSEHOLD

ASSETS AND INDEBTEDNESS OF SOCIAL GROUPS ON 30.6.91, REPORT No. 432, at 21-32 tbls. 5, 14, 15 (1992), MINISTRY OF STATISTICS \& PROGRAMME IMPLEMENTATION, DIFFRENCES IN LEVEL OF CONSUMPTION AMONG SOCIO- 
ECONOMIC GROUPS, REPORT No. 472 At 21 (1991-2000) (Statement 4, Statement 13); Thorat \& Mahamallik, supra note 8, at 13 tbl.1.

Table 7. SC \& ST Quality of Life.

\begin{tabular}{|c|c|c|c|c|}
\hline Health and Education & SC & ST & $\begin{array}{c}\text { Non } \\
\text { SC/ST }\end{array}$ & All \\
\hline Urban Literacy Rate (\%), (2001) & 68.12 & 69.09 & 81.80 & 79.92 \\
\hline Rural Literacy Rate (\%), (2001) & 51.16 & 45.02 & 62.55 & 58.74 \\
\hline Child Mortality (\%), (2000) & 39.0 & 49.0 & 22.0 & $26.7 *$ \\
\hline Access to Public Amenities & & & & \\
\hline $\begin{array}{c}\text { Proportion of Households with toilet facilities } \\
\text { (\%), (1991) }\end{array}$ & 11.16 & 7.22 & 28.63 & $24.07^{*}$ \\
\hline $\begin{array}{c}\text { Proportion of Households with access to } \\
\text { portable water (\%), (1991) }\end{array}$ & 63.60 & 43.21 & 64.10 & $62.35^{*}$ \\
\hline $\begin{array}{c}\text { Proportion of Households with electricity } \\
\text { connection (\%), (1991) }\end{array}$ & 28.10 & 22.80 & 48.06 & $42.79^{*}$ \\
\hline
\end{tabular}

* Extrapolated from population proportions.

GOV'T OF INDIA PLANNING COMM'N, NATIONAL HUMAN DEVELOPMENT REPORT (2002) (tbls. 3.5, 3.7, 3.12 \& 5.9); Thorat, supra note 7, at 13.

Table 8. Percentage of Households with no literate adults of age 15+, by Social Group.

\begin{tabular}{|c|c|c|c|c|c|c|c|c|}
\hline & SC & SC & ST & ST & BC* & BC & SA** & SA \\
\hline $\begin{array}{c}\text { Men \& } \\
\text { Women (\%) }\end{array}$ & $\begin{array}{c}\text { Women } \\
\text { Only }\end{array}$ & M\&W & W O & M\&W & W O & M\&W & W O \\
\hline Urban & 14.8 & 33.8 & 14.3 & 30 & 10.3 & 24.2 & 8.4 & 10.8 \\
\hline Rural & 32.7 & 60.5 & 38.1 & 61.9 & 25.7 & 51.4 & 15.9 & 34.1 \\
\hline
\end{tabular}

Source - Krishnan, 2007

* Backward Classes, ** Socially Advanced

In addition, social inequality also manifests itself in regional and spatial inequality. If one were to consider possession of land assets, it is seen that nearly two-thirds of the 16 per cent Dalits of India are either completely landless or nearly landless with virtually no employment or income generating assets of their own. Even when the Dalits try their hand at entrepreneurship the scene is no different. The Social universe of business has been so completely controlled by certain caste communities that when Dalits come into the business they are invariably seen as 'odd actors'. Their caste identity gets fore-grounded, over and above their professional or business identity (Jodhka, 2010). Health care access to Dalits is no different. A recent survey showed that most Dalit children experienced caste-based discrimination in dispensing of medicine $(91 \%)$ followed by the conduct of the pathological test (87\%) (Acharya, 2010). 
These discrimination driven disparities that the Dalits face have a yoyo-effect on each other. That is one leads to the other and back. Thus the combinatorial effect it has on the lives of marginalized classes is devastating. It is therefore important that society finds a way to uplift the lot of the marginalized class especially in a caste-based societies like India. It is for no fault of theirs that the Dalits have had no access to a civilized life. In fact, some even point it to being a 'karmic' fate. But civilized societies are those that find it in them to ensure the marginalized are brought back to the mainstream. This may require hand-holding which takes many forms. The best of it is what justifies the act of taxation. The rich must count it lucky to be possessors of wealth in a caste society and thus must have a natural obligation to contribute to the betterment of the dispossessed, caste-discriminated classes. Taxing the rich can be seen as part of affirmative action engaged in by a casteist society that wants to rid itself of the evils of its past.

\section{CONCLUSION}

Tax \& Justice

The very term 'justice' applies to those who have been wronged against. Justice is not sought by the un-wronged. Societies seek to recompense those who have been wronged against. Judicial systems exist to dispense justice. But they could be blind to what's been committed as a wrong for centuries past, some of which may even have legal sanction. How then can such social evils be recompensed for? Especially those that arise out of the ills of a caste system?

All societies must at some point in time make moral choices that right the wrongs of the past. Some societies have chosen to apologize. Others have found ways to uplift the downtrodden classes. The latter is practiced through affirmative action. But I believe government must go beyond just affirmative action in its most common form. What it must do is use taxes to lend a helping hand to the dispossessed and disenfranchised. This is what justifies wholly the act of taxation. The answer to setting right an evil social more is through taxes that seek to right wrongs of a discriminatory past. Taxes are most justified when they seek to right social wrongs. They are moral when they take from the unfairly advantaged wealthy to uplift the oppressed in societies where the latter find themselves in that state due to a socially sanctioned evil.

Rewarding the slothful with taxes collected from the ones who have been at their industrious best is morally wrong. After all it is but natural that sloth must beget penury. Then why redeem those that have been slothful? Redemption if deserved must wholly go to the oppressed classes. On their own surely these classes do their personal bit. In places like India they even go to the extent of relinquishing their by birth casteist religion to adopt another that practices equality. The father of the Indian Constitution himself did so along with a multitude of followers when he adopted Buddhism as his personal religion (Jaffrelo,t 2009). But individual actions aren't enough. Society must collectively take the responsibility of righting wrongs. And its representative mouthpiece, the government must play the lead role. Government must employ taxes to provide for the downtrodden classes.

All taxes collected cannot be used solely for the upliftment of the oppressed classes. There are other duties and functions the government must perform to keep the bearings of a civilized society. Yet in maintaining social order what must not be forgotten is the role of the government in being a harbinger to social equality. There may be no other task the government performs that could be nobler or more just. Giving people a chance at being treated fairly must not be restricted to being an ideological pursuit. It must also translate into discernible action on 
the ground. For the Dalits, that action would mean a contribution by the government towards setting up social infrastructure. It would translate on ground into homes, schools, health centers and their like. The purpose of such infrastructure would be to support the Dalits find a way back on to the social mainstream.

If there were to be wholehearted support on part of citizenry towards being taxed, this would be the reason that will get them to willingly contribute. Because in doing so they become part of society's search and realization of what will truly be social justice.

Thus it can be said, if there is a place for tax and justice, it is this one.

** The term 'Dalit has been used interchangeably in this essay to mean the discriminated classes based on Caste.

\section{References}

[1] Acharya, Sanghamitra (2010), 'Access to Healthcare and patterns of discrimination: A Study of Dalit children in selected villages of Gujarat and Rajasthan', Working Paper, Indian Institute of Dalit Studies.

[2] Barth Fredrik (1971), "The System of Social Stratification in Swat, North Pakistan" in E.R. Leach (ed.), Aspects of Caste in South India, Ceylon and North West Pakistan, pp. 113-148, Cambridge: Cambridge University Press.

[3] Cohn B. (1996), Colonialism and its Forms of Knowledge: The British in India, Princeton: Princeton University Press.

[4] Dalit Solidarity Network (2006), 'The Caste System in India - A brief overview: Economic Social exclusion, and the Ambedkar principles of Employment'.

[5] Hofer Andras (2005), The Caste Hierarchy and the State in Nepal, A Study of the Muluki Ain of 1854, First published 1979, Reprint 2005, Himal Books: Lalitpur, Nepal. (1971), "Caste in Jaffna" in E.R. Leach (ed.) (1971), Aspects of Caste in South India, Ceylon and North West Pakistan, pp 61-77, Cambridge: Cambridge University Press.

[6] Economist (2008), 'Clean-up: How to abolish a dirty, low-status job. ', July Edition.

[7] Jaffrelot Christopher (2009), 'Dr. Ambedkar's Strategies Against Untouchability and the Caste System.' Working Paper, Indian Institute of Dalit Studies.

[8] James E. Meade (1952), A Geometry of International Trade (London: Allen \& Unwin), p. 112.

[9] Jodhka Surinder (2010), 'Dalits in Business: Self Employed Scheduled Castes in North India', Working Paper, Indian Institute of Dalit Studies.

[10] Jodhka Surinder, Shah Ghanshyam (2010), 'Comparative Contexts of Discrimination: Caste and Untouchability in South Asia, Working Paper, Indian Institute of Dalit Studies.

[11] John Rawls (1971), A Theory of Justice, p. 102.

[12] Leach E. R. (1960), "Introduction: What should we mean by caste?" in E.R. Leach (Ed.), Aspects of Caste in South India, Ceylon and North West Pakistan, Cambridge: Cambridge University Press. 
[13] Munshi K., M. Rosenweig (2005), Why is Mobility in India so Low? Social Insurance, Inequality, and Growth. Cambridge: Harvard BREAD Working Paper No.097.

[14] Narasimhchary M, (2002), 'The Caste System - An overview', IK Foundation Lecture series.

[15] Sarabhai M. (2010), 'India's secret shame', The Week, October Edition.

[16] Sowell M. (2010), 'On Taxes, rhetoric of deception rules', Redding. 